\title{
Quantification of magma ascent rate through rockfall monitoring at the growing/collapsing lava dome of Volcán de Colima, Mexico
}

\author{
S. B. Mueller ${ }^{1, *}$, N. R. Varley ${ }^{2}$, U. Kueppers ${ }^{1}$, P. Lesage ${ }^{3}$, G. Á. Reyes Davila ${ }^{4}$, and D. B. Dingwell ${ }^{1}$ \\ ${ }^{1}$ Earth \& Environmental Sciences, Ludwig Maximilians University (LMU), Munich, Germany \\ ${ }^{2}$ Facultad de Ciencias, University of Colima, Colima, Mexico \\ ${ }^{3}$ Institut des Sciences de la Terre, Université de Savoie, CNRS, Le Bourget-du-Lac, France \\ ${ }^{4}$ Centro Universitario de Estudios e Investigaciones en Vulcanología, Universidad de Colima, Colima, Mexico \\ * now at: Lancaster Environment Centre, Lancaster University, UK
}

Correspondence to: S. B. Mueller (s.mueller1@lancaster.ac.uk)

Received: 11 December 2012 - Published in Solid Earth Discuss.: 15 January 2013

Revised: 2 June 2013 - Accepted: 3 June 2013 - Published: 11 July 2013

\begin{abstract}
The most recent eruptive phase of Volcán de Colima, Mexico, started in 1998 and was characterized by dome growth with a variable effusion rate, interrupted intermittently by explosive eruptions. Between November 2009 and June 2011, activity at the dome was mostly limited to a lobe on the western side where it had previously started overflowing the crater rim, leading to the generation of rockfall events. As a consequence of this, no significant increase in dome volume was perceivable and the rate of magma ascent, a crucial parameter for volcano monitoring and hazard assessment could no longer be quantified via measurements of the dome's dimensions. Here, we present alternative approaches to quantify the magma ascent rate. We estimate the volume of individual rockfalls through the detailed analysis of sets of photographs (before and after individual rockfall events). The relationship between volume and infrared images of the freshly exposed dome surface and the seismic signals related to the rockfall events were then investigated. Larger rockfall events exhibited a correlation between its previously estimated volume and the surface temperature of the freshly exposed dome surface, as well as the mean temperature of rockfall mass distributed over the slope. We showed that for larger events, the volume of the rockfall correlates with the maximum temperature of the newly exposed lava dome as well as a proxy for seismic energy. It was therefore possible to calibrate the seismic signals using the volumes estimated from photographs and the count of rockfalls over a certain period was used to estimate the magma extrusion flux for the period investigated. Over the course of the mea-
\end{abstract}

surement period, significant changes were observed in number of rockfalls, rockfall volume and hence averaged extrusion rate. The extrusion rate was not constant: it increased from $0.008 \pm 0.003$ to $0.02 \pm 0.007 \mathrm{~m}^{3} \mathrm{~s}^{-1}$ during 2010 and dropped down to $0.008 \pm 0.003 \mathrm{~m}^{3} \mathrm{~s}^{-1}$ again in March 2011 . In June 2011, magma extrusion had come to a halt. The methodology presented represents a reliable tool to constrain the growth rate of domes that are repeatedly affected by partial collapses. There is a good correlation between thermal and seismic energies and rockfall volume. Thus it is possible to calibrate the seismic records associated with the rockfalls (a continuous monitoring tool) to improve volcano monitoring at volcanoes with active dome growth.

\section{Introduction}

Volcán de Colima is located in Mexico at $19^{\circ} 51^{\prime} \mathrm{N}$, $103^{\circ} 64^{\prime} \mathrm{W}$ (Fig. 1). The altitude of the dome during the observation period January 2010 to June 2011 was $3850 \mathrm{~m}$. The volcano is located at the western extreme of the TransMexican Volcanic Belt and is characterized by calc-alkaline magma, generated as a result of the subduction of the Riviera-Cocos Plates beneath the North American Plate.

The behaviour of Volcán de Colima has shown cyclicity over several different orders of magnitude of time. The last major eruptive cycle ended with a Plinian eruption in 1913. Following the filling of a deep excavated crater, further discrete effusive events formed summit domes with flank 


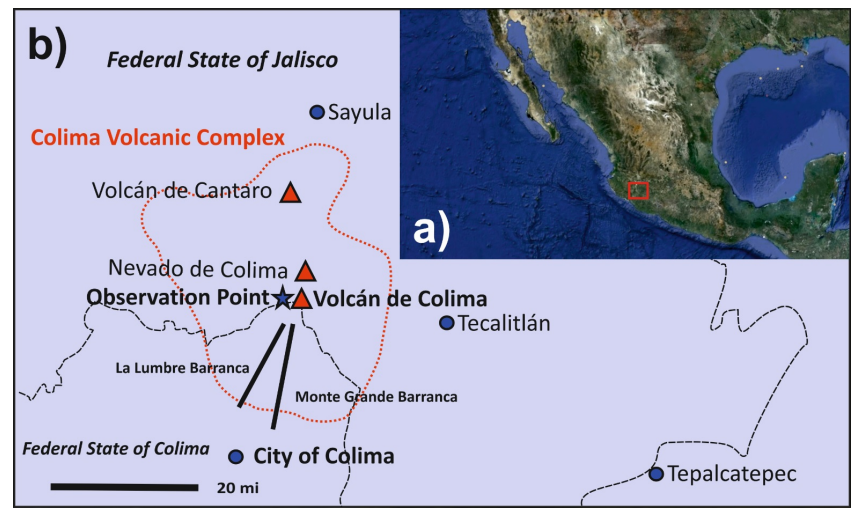

Fig. 1. (a) Position of Volcán de Colima in Mexico (Red box); (b) map showing the Colima Volcanic Complex with the extinct volcanoes Volcán de Cántaro and Nevado de Colima and the active Volcán de Colima (red triangles). Two black lines south of Volcán de Colima show the two main ravines leading towards the City of Colima; in the case of dome collapse events, such ravines guide pyroclastic flows. Also the observation point Playón in the west of Volcán de Colima where data for this study has been collected is shown (blue star).

lava flows; the first in 1961 and ending in 1962 (Luhr and Carmichael, 1980). The last eruptive period started in 1998 and was primarily effusive (lava flows and domes). During this period, Volcán de Colima showed a great variability in magma extrusion rates. The final dome started growing in early 2007 (Varley et al., 2010a) and stopped in June 2011. It was characterized by exceptionally slow growth rates throughout. Once the dome reached the crater rim, it began to overflow mainly down the western flank and to minor extent down the southern and northern rims. This was due to growth within the crater being offset from the centre (Fig. 2).

Many other lava domes have shown similar behaviour to Volcán de Colima: Soufrière Hills on Montserrat, West Indies (Loughlin et al., 2010; Ryan et al., 2010); Mount St. Helens, USA (Smith et al., 2011); Santiaguito dome, Guatemala (Rose and Pattern, 1972); Mount Unzen, Japan and Shiveluch, Kamtchatka (Barmin et al., 2002).

The magma effusion rate at Volcán de Colima has frequently varied: 1998-1999 and 2004 were characterized by a fast rate $\left(>5 \mathrm{~m}^{3} \mathrm{~s}^{-1}\right)$ whereas it was low in 2001-2003 and 2007-2011 $\left(<1 \mathrm{~m}^{3} \mathrm{~s}^{-1}\right)$ (Varley et al., 2010a). In comparison to other volcanoes, the Volcán de Colima extrusion rate between 2007 and 2011 was unusually low: the average magma extrusion rate at Soufrière Hills during the 20052008 dome growth period was $5.6 \mathrm{~m}^{3} \mathrm{~s}^{-1}$ (Ryan et al., 2010). The Mount St. Helens extrusion rate during the 2004-2008 dome growth period was typical starting fast $\left(6 \mathrm{~m}^{3} \mathrm{~s}^{-1}\right.$ in 2004) and then gradually decreasing to less than $1 \mathrm{~m}^{3} \mathrm{~s}^{-1}$ in 2008 (Smith et al., 2011).

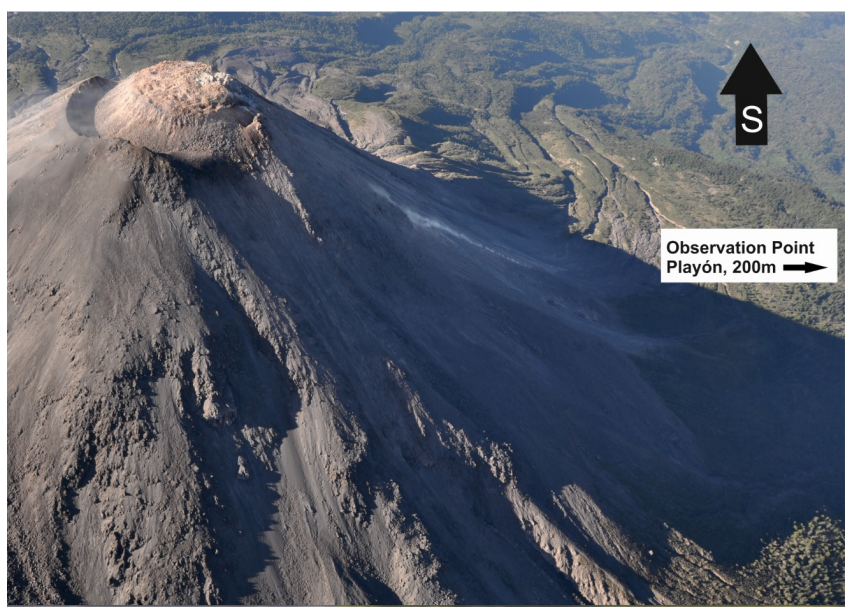

Fig. 2. Photograph shows Volcán de Colima and the location of the observation camp within the Playón to the west of the volcano. The image shows the decentralized growing dome of Volcán de Colima. The dome has a diameter of $298 \mathrm{~m}$ and can be used as a scale. The white dust track down the slope was triggered by a recent rockfall.

Since 2003, Volcán de Colima has been characterized by daily Vulcanian explosions as a result of crystallization, pressurization and subsequent explosions (Varley et al., 2010a). Each of the four episodes of dome growth at Volcán de Colima since 1998 has been followed by more acute explosive activity. In 2005, a series of larger Vulcanian eruptions took place during a period of elevated effusion rate. Varley et al. (2010b) studied the events that occurred between February and September 2005 in detail; at least 30 pyroclastic flows were produced from column collapse. This represented the most intense period of activity since the 1913 Plinian eruption.

\subsection{Dome growth and rockfalls}

Magma rises due to buoyancy differences with the surrounding country rock. At high viscosities, the erupted magma tends to remain close to the vent rather than forming lava flows, leading to relatively tall extrusions. The shape of a dome is controlled by the interplay of ascent rate (affecting the cooling history and thereby the viscosity) and magma properties (composition, bubble and crystal content, each affecting the rheological properties). Degassing, cooling and compaction may lead to the formation of a dense plug with a greatly reduced permeability. The consequent reduction of degassing potential leads to an increased risk of explosions. Rocks from Volcán de Colima however can regain their permeability quickly following an explosive event through the healing of tuffisite veins as described by Kolzenburg et al. (2012). 
Dome growth can take place either endogenously or exogenously. Endogenous growth occurs when magma intrudes into the dome interior, exogenously growth by extrusion as new surface lobes (Fink et al., 1990). The type of dome growth may have an important bearing on volcanic hazard issues. Exogenous growth usually builds steeper and more unstable domes; this can lead to the generation of blockand-ash flows or rockfalls and makes them more prone to collapse (Nakada, 1996). Endogenous growth, on the other hand, may increase gas accumulation within the edifice, thus enhancing the chance of violent, explosive eruptions (Rose et al., 1977; Fink et al., 1990; Nakada et al., 1995). Activity at lobate domes, like the one at Volcán de Colima, can fluctuate between exogenous and endogenous; this was observed for example during the 1980-1986 Mount St. Helens dome growth period (Fink et al., 1990). A similar, more recent study has been carried out at Unzen volcano, Japan; fluctuation between endogenous and exogenous growth was observed during the 1991-1995 eruption (Kaneko et al., 2002) and was explained by variations in the rate of extrusion.

The four dome growth episodes at Volcán de Colima during the last period (1998 to 2011) mainly took place endogenously, partly exogenously; a similar situation is described by Major et al. (2009) who describe the 2004-2008 lava spine extrusion and mainly endogenous growth at Mount St. Helens, USA. For the 2007-2011 eruption at Volcán de Colima, growth was exogenous from 2009 to 2011, during which time the dome formed a lobe which was overflowing the western crater rim.

The dome of Volcán de Colima was shaped as a truncated cone that filled most of the summit crater (Fig. 2). Its carapace consisted of variably sized blocks of cooled and crystallized lava. The flanks of the dome exhibit a slope angle of approximately $38^{\circ}$. Blake (1990) describes four kinds of domes (upheaved plugs, lava domes, low lava domes and coulees); however, it is difficult to assign one of these categories to the recent Volcán de Colima domes. They could be classified as between the lava dome and the low lava dome types, since they have the typical dome slope angle $\left(\sim 38^{\circ}\right)$ of a "lava dome" and were usually observed to degas through their surface, that is typical for "low lava domes". On the other hand, a typical spine never formed like the 2004-2008 dome at Mount St. Helens; and neither was the typical flat slope angle $\left(10^{\circ}-15^{\circ}\right)$ of low lava domes demonstrated. A typical low lava dome was the dome at Soufrière de St. Vincent, West Indies.

Domes can lose volume by (1) gravitational instabilities, (2) explosive eruptions or (3) collapsing vesicles (Kennedy et al., 2012). Obviously, one can trigger the other. The style with which material is transported away from the dome in the case of gravitational instabilities is a function of the growth conditions (pressure and temperature distribution) and the volume of dome collapse. Also severe weather conditions such as intense rainfall can influence gravitational stability of a dome. Rainwater can infiltrate cracks and build up pressure by vaporization (e.g. Taron et al., 2007). This might result in the rockfall occurring earlier in time but since there was active effusion at Volcán de Colima, an increase in the total volume of material involved in rockfalls is unlikely. We cannot rule out a variation in the magnitude-frequency distribution of rockfall events, but this should not affect effusion rate estimates. Of course phreatic activity is generally more likely during the rainy season and could largely affect rockfall frequency and intensity; however, Volcán de Colima shows no evidence of having a hydrothermal system and the edifice is generally well drained.

Small volume collapse or collapse from slow-growing domes will most commonly lead to rockfall events. If larger volumes from a faster growing dome are affected, pyroclastic density currents may be generated. In this case a continuum between rockfalls and density currents would be observed. Generally speaking, the transport properties may change as a response to the morphology along the path. The deposition of coarse material and/or entrainment of ambient air will significantly increase the mobility of the density current.

Monitoring rockfalls is important because it can contribute to real-time hazard assessment and help in examining the activity of a volcano. The effusion rate is a critical parameter for determining the style of activity and hence the hazards associated with an erupting volcano.

Rockfalls can lead to many threatening situations to mankind or the environment. Moran et al. (2008) describe an unusually large rockfall at Mount St. Helens, which occurred in May 2006. The rockfall triggered an atmospheric plume that rose to $6000 \mathrm{~m}$, which could possibly have affected air traffic. At Volcán de Colima, a pyroclastic flow in October 2004 travelled as far as $6.1 \mathrm{~km}$ in the La Lumbre ravine. Simulations have shown that large dome collapses would threaten many of the ranches that surround the volcano (Sulpizio et al., 2010). The last major pyroclastic flow of the 1998-2011 eruption was generated by an explosion in September 2005 and marked the end of the 2004-2005 period of activity (Varley et al., 2010b). For this reason, continuous monitoring of dome activity at active volcanoes such as Volcán de Colima is crucial; it provides important information for hazard mitigation as can be seen at other active volcanoes such as Merapi, Indonesia (Hort et al., 2006).

Several studies have recently investigated the characteristics of the seismicity generated by rockfalls. Hibert et al., 2011, analysed seismic signals (shape, duration and frequency) associated with rockfalls at Piton de la Fournaise, Réunion. Signals were generally symmetric with a slowly increasing amplitude to a peak near the middle of the event, then followed by a similarly slow decrease. Their duration varied between $50 \mathrm{~s}$ and more than $200 \mathrm{~s}$ with an average peak frequency of $5 \mathrm{~Hz}$. Rockfall signals were registered on four short-period stations between 600 and $2100 \mathrm{~m}$ from the centre of the crater. A link between deflation of the summit dome, following crater floor collapse and rockfall activity was found. This feasibility and validity of using 
seismicity for estimating fundamental rockslide event parameters has also been described by Norris (1994) and Dammeier et al. (2011); they used rockslide metrics (such as signal duration, peak value of the ground velocity envelope, velocity envelope area, rise time and average ground velocity) to estimate e.g. rockslide volume, runout distance, drop height, potential energy and gradient of the slope.

More general studies regarding relations between rockfall properties and seismicity have been investigated previously: a rockfall analysis at Soufrière Hills volcano by Calder et al., 2005 , describes a link between changing rate of growth of the 1995-1997 lava dome and both the frequency of occurrence of rockfalls and their duration determined using the seismic signals. A similar study to this was also carried out during the 2004 andesitic block-lava extrusion at Volcán de Colima: finding a link between seismic signal duration of rockfalls, energy of explosions and temporal variations in the number of rockfalls and explosions (Zobin et al., 2008). They compared rockfall frequency with both the rate of magma discharge and $\mathrm{SO}_{2}$ emission; rockfall appearance and subsequent disappearance was found to clearly indicate the beginning and the end of the extrusion.

Feasibility and validity of using seismicity for detection, localization and size determination of rockfalls at Montserrat in Catalonia, Spain, has been described by Vilajosana et al. (2008). Rockfall volume was in a first instance obtained by using a laser scanner and then correlated to the seismic signals. One step further to laser scanner methods has been undertaken by Jongmans and Garambois (2007) who used 2-D and 3-D geophysical imaging methods for investigating structures of rockfall areas.

Rockfalls at Volcán de Colima during the recent activity were small, due to a very low effusion rate and occurred up to 20 times a day within the monitored time frame for this paper (March and April 2011). The section of the dome observed from the Playón observation point to the west of the volcano during March and April 2011 had a diameter of approximately $298 \mathrm{~m}$, which had not varied since the end of 2009. Up to 60 rockfalls a day were recorded in 2010, when the effusion rate was higher.

Active domes have been investigated by seismic, Doppler radar and photographic methods; e.g. the growth rate of the Soufrière Hills lava dome was assessed for the period of 2005-2008 using four different approaches: terrestrial photos, ground based lidar, ground based radar and an empirical method using photographs of dome profiles (Ryan et al., 2010). Only the photographic method was used regularly, as it was the most simple. However, as it was only possible to take photos from two locations around the dome, systematic errors arose. Photo-based dome monitoring was first carried out by Sparks et al. (1998) for the first episode of lava dome growth within the current eruption at Soufrière Hills volcano.

The situation at Volcán de Colima was different; since growth of the dome essentially stopped after November 2009, when the dome reached the western crater rim and magma input into the dome was immediately compensated in the form of rockfalls, a different approach to determine the magma extrusion rate had to be developed. A photographic method is still applicable, though not by correlating different dome profiles, but by examination of dome images showing variation of the surface features due to removal of material through rockfalls.

\subsection{Seismicity at Volcán de Colima}

Of the studies already mentioned, Hibert et al. (2011), Dammeier et al. (2011), DeRoin and McNutt (2012) and DeRoin et al. (2012) used seismic data to analyse rockfall or block-and-ash flow events at other locations. Less work has been done on the analysis of the number of rockfall events, e.g. Calder et al., 2005, examined rockfall frequencies during an andesite lava dome eruption at Soufrière Hills volcano, Montserrat, and described repose intervals between rockfalls correlating with log-logistic survivor distributions.

In this study we use rockfall generated seismicity to simply calculate an empirical relationship between rockfall volume and the corresponding proxy for seismic energy. However, we do not offer an in-depth investigation of seismic rockfall signals at Volcán de Colima since it was not necessary for the purpose of our study.

Beneath Volcán de Colima volcano-tectonic (VT) swarms, long-period (LP) events and tremor events have been detected. VT swarms were mainly detected prior to the 19981999 effusive eruption; however, during and after the eruption the seismicity changed to LP and hybrid events (Zobin et al., 2002). During the recent eruptive episode, four types of signals dominated: tremor, which sometimes was harmonic, small magnitude LP events, larger magnitude isolated LP events or LP events with a diminishing coda (Varley et al., 2010a), similar to tornillos which are defined for Galeras (Gil Cruz and Chouet, 1997) and explosion earthquakes.

Rockfalls at Volcán de Colima can be readily identified by their seismic signal; surface processes at volcanoes in general, like lahars, pyroclastic flows or rockfalls produce seismic signals that typically show a slowly increasing and then decreasing, long-duration seismic waveform. They can last up to several minutes and have a high peak frequency (> 5 Hz) (Shearer, 2009). For accurate rockfall monitoring at Volcán de Colima the seismic network RESCO (Red Sismológico de Colima) is sufficient. The network consists of four short-period and four broadband stations. The signals of the EZV4 station were used, it being the closest station to the volcano (1.9 km from the crater). The short-period signals are telemetered to the University of Colima and digitized with a 16 bit A/D (analog to digital) converter, whereas the broadband sensor uses a 24 bit A/D converter and digital transmission. Signals are sampled at a frequency of $100 \mathrm{~Hz}$. During the visual observation period of this study, all rockfalls originated at the same location from the dome. Accordingly, the 


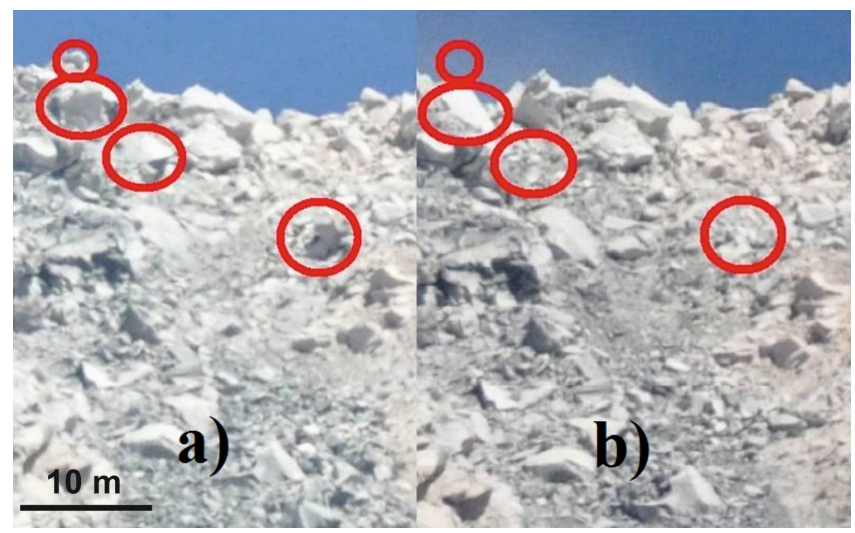

Fig. 3. View of the dome of Volcán de Colima (a) before the rockfall on the 8 March 2011, 15:02 LT (21:02 GMT) and (b) after the rockfall. Rocks that are missing after the rockfall are marked with a red circle.

path dependence of the seismic signal was considered minor and not taken into consideration.

In a seismic signal study carried out at Volcán de Colima by Arámbula-Mendoza et al. (2011) the 2004-2005 period of large eruptive activity was investigated, during which rockfall signals always showed a clearly identifiable seismic waveform and had a high frequency range between 1 and $15 \mathrm{~Hz}$.

\subsection{Thermography used in volcano monitoring}

Thermography is applicable for many monitoring problems: the spatial distribution of temperatures related to degassing and/or eruptive activity or the detection of anomalies in a time series; and they can be used for deriving heat fluxes and effusion rates (Calvari et al., 2007; Hutchinson et al., 2013). Higher gas fluxes usually result from more intense magmatic activity; an increase of fumaroles' gas temperature has been commonly observed prior to eruptions or shallow magma intrusions (e.g. Menyailov et al., 1986).

At Volcán de Colima, thermal images are obtained from flights, handheld ground based observations and temporary fixed stations. These images are not only used for rockfall monitoring, but also for thermal surveys of growing domes, fumaroles or for the thermal gradient of ash plumes. Fumaroles on the crater rim have been routinely monitored from a fixed location at Volcán de Colima since 2004 (Stevenson and Varley, 2008). Anomalies like a sharp drop in fumarole heat fluxes coincided with the emergence of the lava dome in the summit crater in 2007. Also a general, long-term drop of fumarole temperatures between January 2006 and August 2007 coincided with a decrease in the explosivity of the volcano (Varley and Reyes, 2013). For this study, thermal images were used to investigate the thermal signature of rockfalls at Volcán de Colima.

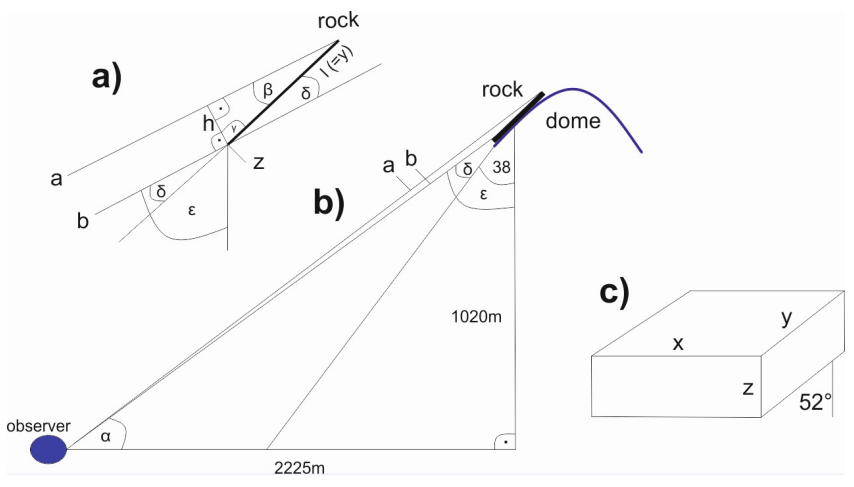

Fig. 4. Drawing shows (a) a detailed view of the dome, (b) the entire situation between observer and rock on the dome and (c) the rock aces $x, y$ and $z$.

\section{Methodology}

A 12 day field campaign was conducted at Volcán de Colima during March and April 2011, with 86 rockfall events monitored, which represented about $7 \%$ of the total number of rockfalls for that period. Observations were made from a base about $2.2 \mathrm{~km}$ from the volcano, to the west, within the Playón, the relatively flat floor of a collapsed caldera (Figs. 1, 2).

\subsection{Direct observation}

The volume of individual rockfall events was estimated through a comparison of sets of high-resolution photos of the dome before and after rockfall events (Fig. 3). The goal was to identify blocks or entire dome sections that were quantifiable in size before a rockfall and were subsequently removed during the event. For obvious reasons, this technique only works during daylight. Additionally, the image quality was negatively affected by the sun position behind the volcano (morning) and at times reduced visibility due to meteorological or volcano degassing conditions. As a consequence, we used the data of 23 out of 86 recorded events for this study.

A Nikon D90 SLR (single lens reflex camera) with a resolution of 12.2 megapixels and a $300 \mathrm{~mm}$ lens was used. The raw photos were digitally sharpened by using the opensource software Paint.Net, which allowed blocks larger than $20 \mathrm{~cm}$ to be easily recognized and defined.

In order to calculate the volume of a block on the dome, one needs to define three orthogonal axes (Fig. 4c): axis $y$ being parallel to the slope; $x$ perpendicular to the gradient. Axis $\mathrm{z}$ is perpendicular to the surface of the slope (Fig. 4). For further calculations, rocks are assumed to have an ideal cuboid shape with 6 faces. The true length along the $\mathrm{x}$-axis could be simply measured because the geometrical line of sight between viewer and rock did not influence it. The line of sight did, however, influence the measurement of the length along the y-axis. The horizontal distance between 
observer and dome was $2225 \pm 10 \mathrm{~m}$; the vertical distance was $1020 \pm 10 \mathrm{~m}$. Both assumed errors of $\pm 10 \mathrm{~m}$; this affects the final result of the rock volume in question by less than $0.4 \%$ and will be considered in our final error estimation. The oblique angle of view had to be taken into consideration. The apparent length $h$ along axis y can be used to calculate the true length $l$ as shown in Fig. $4 \mathrm{a}$ and $\mathrm{b}$. The thick, black line on the dome represents the block in question. Lines a and b (Fig. 4b) are assumed to be parallel for our calculations, however the deviation from parallelism will increase with rock size resulting in an error term proportional to size (see discussion for error calculation); with a being the line between observer and the top of the rock, $b$ the line between observer and the bottom of the rock. The rock rests on the slope of the dome; the slope angle of the dome is on average $\gamma=38 \pm 3^{\circ}$, estimated from photos from flights obtained at the same altitude as the dome. As rocks are approximated to cuboids, they share the same gradient as the dome slope. Rocks on the dome carapace of Volcán de Colima are angular due to dome growth and cooling processes. Figure 4a shows the geometry; $l$ is the real length of the rock, whilst the apparent length $h$ is measured directly from the photographs (with an average error of $25 \%$, see discussion). $l$ can be calculated as follows:

$l=\frac{h}{\sin \beta}=\frac{h}{\sin (\varepsilon-\gamma)}$,

as $\beta=\delta$ and $\tan \varepsilon=\frac{2225}{1020}$,

where delta is $27^{\circ}$. Finally, the length of the block along the $\mathrm{z}$-axis, normal to the dome surface, needs to be determined. In some cases this was hard to detect in the pictures taken from the Playón. Analysis of photos taken during previous flights has been performed and no more flights were required. We found that the length along the z-axis was always the shortest axis. The length pointing downwards along axis y was always the longest axis. The length of the $x$-axis however is somewhere between the values of the $y$ - and $z$-axes.

Taking the average values of the axes of the rocks in the photos, the following empirical relationships were found:

$x=2.11 z($ standard deviation $\mathrm{SD}=0.9)$,

and $y=3.02 z(\mathrm{SD}=1.3)$.

These ratios provide an alternative method to estimate the length of the z-axis. For calculating the volume of individual blocks, a near-vertical face that was generated during the rockfall was measured if possible; scaling this face with the ratios of the axes gives us the most accurate possible length of each individual z-axis. With the known dome diameter (298 $\mathrm{m}$ viewed from the observation base in the west) which was used as a scale, the resulting calculation of all three lengths and the given rock shape assumptions, the rock volume could be obtained.

\subsection{Thermal imagery}

For thermal imagery, a VarioCam hr from InfraTec ${ }^{\circledR} \mathrm{GmbH}$ (Germany) with a $640 \times 480$ array was used in this study. Based on the distance, this allowed for a detailed analysis of the entire visible dome surface $\left(28000 \mathrm{~m}^{2}\right)$ as each pixel has the dimension of $4.5 \mathrm{~m} \times 4.5 \mathrm{~m}\left(20.25 \mathrm{~m}^{2}\right)$. Results were obtained for all 86 rockfalls events within the observation period.

The camera was set up at the observation site, where it recorded an image of the dome every two seconds continuously, leading to an excellent database for every rockfall during the 12 field days. The thermal images were used for analysing the freshly revealed area on the dome surface after a rockfall, and to investigate the mean temperature of rockfall masses spread over the volcano slope. It should be noted that temperatures stated are the average temperatures for the pixels within the defined area of the infrared image. The thermal images were analysed using the software IRBIS Professional from InfraTec ${ }^{\circledR} \mathrm{GmbH}$.

Every rockfall exposed a new surface with a specific mean and maximum pixel temperature; large volume rockfalls produced pixel temperatures up to $200^{\circ} \mathrm{C}$ hotter than the local pre-rockfall dome exterior. In contrast, in the case of very small rockfalls (volume of only a few cubic metres) it was not always possible to constrain a temperature difference $\Delta T$; those events were noted with a $\Delta T=0^{\circ} \mathrm{C}$. Furthermore, for every rockfall the number of pixels at elevated temperatures on the slope of the volcano could be quantified by careful definition of the areas of interest. In this case the mean temperature was calculated and compared to the estimated volume. By correlating the estimated rockfall volume derived from the photographic images with the $\Delta T$ of the exposed face and the mean temperature of the rockfall masses, it was possible to estimate the rockfall volume solely by using thermal images. Here we demonstrate the approach for defining the temperature of the exposed face. The rockfall event of 8 March 2011 between 15:07 and 15:11 Colima Local Time (LT; 21:07 and 21:11 GMT, Greenwich Mean Time) will be used as an example.

Figure 5 shows a series of three images of the dome (a) prior, (b) during and (c) after the rockfall event. On the images are two circles, $\mathrm{C} 1$ and $\mathrm{C} 2$; $\mathrm{C} 1$ marks the spot where the exposed face will be generated during the rockfall, $\mathrm{C} 2$ marks a spot on the slope, where the rockfall will pass during the event. The maximum temperature for $\mathrm{C} 1$ refers to the pixel with the maximum temperature within the circle $\mathrm{C} 1$ and in this case it was $105.7^{\circ} \mathrm{C}$ before and $305^{\circ} \mathrm{C}$ after the rockfall, giving a difference of $199.3^{\circ} \mathrm{C}$. $\mathrm{C} 2$ shows a maximum temperature of more than $400^{\circ} \mathrm{C}$ for the duration the rocks were within that region. In picture (b), $\mathrm{C} 1$ and $\mathrm{C} 2$ show relatively low temperatures due to the ash generation during the rockfall event which inhibits the temperature recording of the thermal camera. The temperature differences of the exposed dome area before and after each rockfall were then correlated 


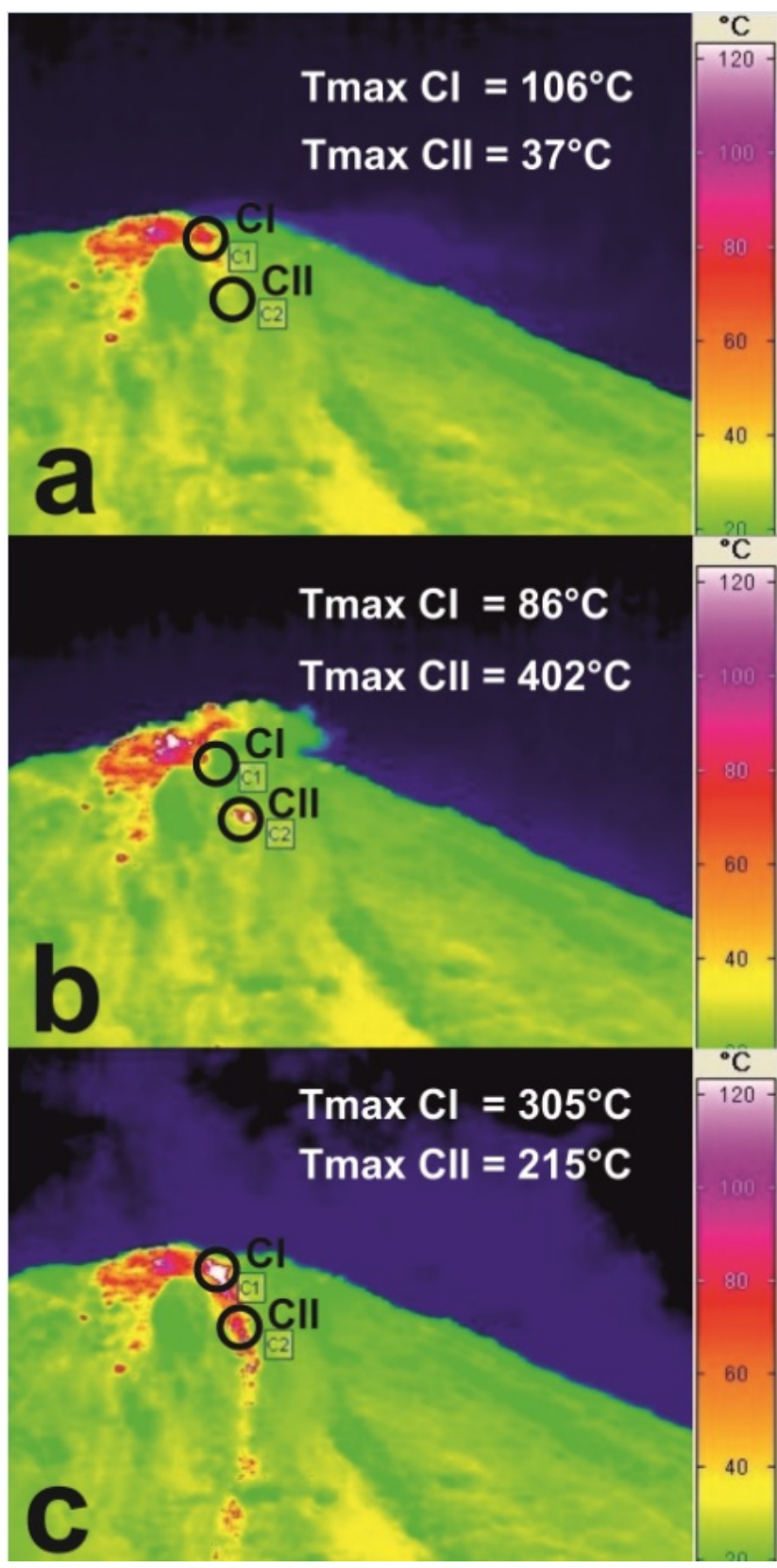

Fig. 5. Series of thermal images of a rockfall on 9 March, 2011 at 21:07 GMT at Volcán de Colima before (a), during (b) and after (c) a rockfall. The black circle $\mathrm{C} 1$ marks the exposed face on the dome; $\mathrm{C} 2$ marks a spot on the slope where the rockfall will pass by. Each picture shows the maximum temperature of each circle which is the basis for the temperature difference measurements. Temperature scales were fixed to better show the distribution of lower temperatures; white areas have temperatures up to $400^{\circ} \mathrm{C}$.

to the estimated volume of rockfalls from the photographic method (Fig. 6).

In Fig. 5c, the hot trace of the rockfall moving down the slope can be seen. The thermal emission from hot rocks rolling down the slope was measured as a time series. The

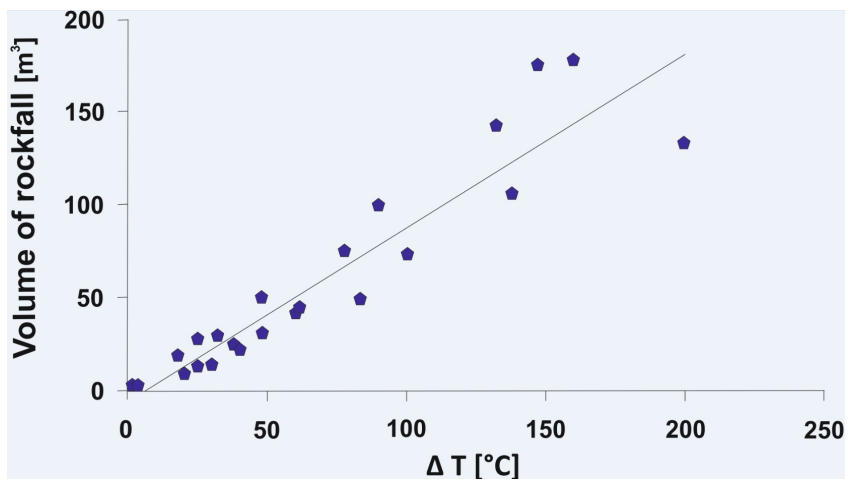

Fig. 6. Relationship of rockfall volume estimated from photos taken before and after and the temperature difference measured at the exposed dome face; $R^{2}$ is 0.88 .

mean temperatures of the traces recorded were then again compared to the rockfall volume (Fig. 7), as estimated from photographs.

\subsection{Energy of associated seismic signals}

The seismic investigation of rockfalls, however, brought an additional challenge: the fact that some rockfalls occur together with small eruptive events, leading to the superposition of the rockfall and eruption signals. Fifteen out of the 23 events with their volume estimated using photographs, however, did not coincide with an eruption, allowing straightforward analysis of the seismic signal. Because rockfall signals are complex, it is not possible to calculate precisely the corresponding energy. Thus we used the integral of the associated velocity signal squared, or the sum of the squares of the samples multiplied by the sampling interval, as a proxy of the energy release. Analysis and calculations were carried out with the Matlab package Seismo_volcananalysis (Lesage, 2009). Figure 8 shows a typical seismic rockfall signal of Volcán de Colima together with its spectrogram.

\subsection{Comparison between the rockfall volume and thermal monitoring}

The volume estimated from the photographs was compared with the measured $\Delta T$ values of the freshly exposed face on the dome and to the mean temperature of the rockfall masses distributed over the slope. A first order correlation between $\Delta T$ and volume $V\left(\mathrm{~m}^{3}\right)$ yields the result $\left(R^{2}=0.88\right.$, Fig. 6$)$ :

$V=0.84 \Delta T$.

This result implies a relationship between the rockfall size and either the area exposed of the hot dome interior, or the depth into the dome uncovered, where higher temperatures would be expected. Due to the large pixel size it is impossible to determine which of the two possibilities explains the 


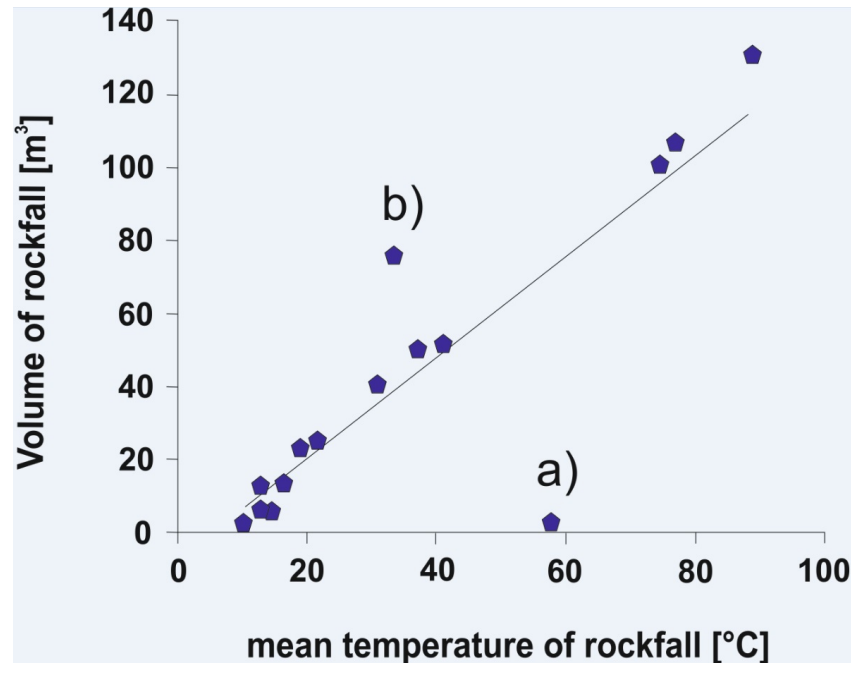

Fig. 7. Relationship between the volume of rockfalls estimated from photos taken before and after and the mean temperature of the related deposits distributed over the volcano's slope. Two outliers can be observed: point (a) marks a rockfall that happened shortly after a large one so the high average $T$ for the observed small volume is not representative. Point (b) marks a rockfall that broke off from the NW edge of the dome. Here rockfall activity was very low; accordingly the involved mass had had more time for cooling, leading to the observed low value of average $T$.

temperature rise, but it would have been dependent upon the geometry of the displaced rocks.

The mean temperature of the rockfall mass on the slope correlated well with the volume of the event. Figure 7 shows estimated volume $V$ vs. mean temperature $T$ of 15 rockfall events. The mean temperature was mostly recorded immediately after final emplacement of rock mass on the slope. However large rockfalls tended to produce larger dust clouds; in these cases it was necessary to wait longer (up to minutes) in order to get a clear view of the slope. Looking at other rockfall data of Volcán de Colima, a time delay of a few minutes in measuring rock temperatures can affect the result by up to $10^{\circ} \mathrm{C}$. Only 15 of the total 23 estimated rockfalls were easily compared because the 8 remaining rockfalls were associated with an explosive event; in this case strong ash generation hindered reasonable measurements due to progressed decay of mean temperatures.

Figure 7 shows a good correlation $\left(R^{2}=0.85\right)$ with the exception of two events. The outlier (a) represents a rockfall that occurred shortly after another large rockfall. Thus it started in an area of the dome with lava exposed that was hotter than average surface temperatures. The second outlier (b) marks a rockfall that broke off at the NW edge of the dome where rockfall activity was low and accordingly the dome interior had cooled over a more substantial period of time.

The ratio between volume and mean temperature of rockfall mass on the slope has been calculated and the following a)

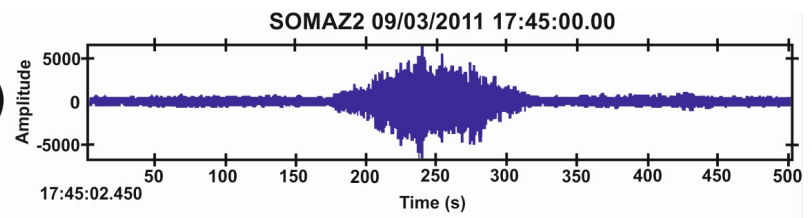

b)

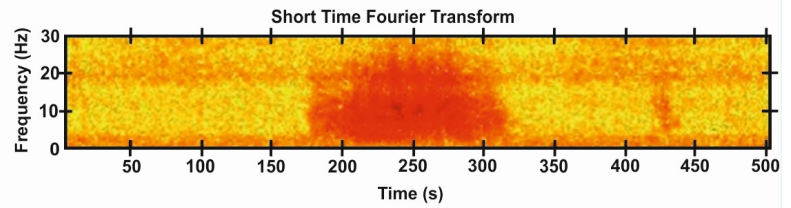

c)

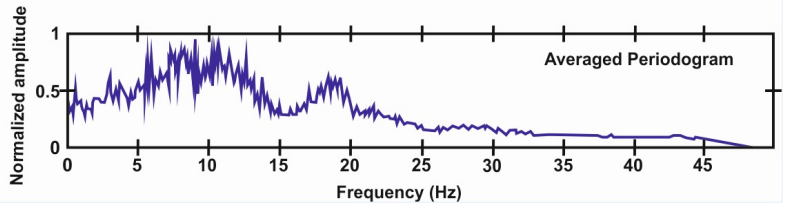

Fig. 8. Rockfall signal at Volcán de Colima with its frequency. Shown are (a) the seismogram and (b) its time-frequency representation and (c) the averaged periodogram of the event. An order 2 high-pass filter was applied with a low corner frequency of $1 \mathrm{~Hz}$. The rockfall was recorded at SOMA station at 17:48 GMT on 9 March 2011.

relationship has been found:

$V=1.25 T$.

Using this relationship, an estimation of the volume of rockfalls is possible based solely on thermal images.

\subsection{Comparison between rockfall volume and seismic energy}

The proxy for seismic energy $E^{\prime}$ was estimated for the signals associated with 15 rockfalls. A remarkably good correlation was observed between $E^{\prime}$ and $V$ (Fig. 9). Therefore $E^{\prime}$ can be used to estimate rockfall volume $V$ at Volcán de Colima, at least for activity similar to that studied in this paper.

The correlation between estimated volume of rockfalls $V$ and pseudo-energy $E^{\prime}$ gives the following empirical relationship:

$V=209.98 E^{\prime}$.

With $V$ in $\mathrm{m}^{3}$ and $E^{\prime}$ calculated from seismic velocity (in $\mathrm{ms}^{-1}$ ). This analysis was only possible for rockfalls without simultaneous eruptive or ash-venting events. A range of $E^{\prime}$ from $0.007-0.6$ was obtained for rockfalls analysed in this study.

\subsection{Magma extrusion rate}

After the dome at Volcán de Colima started overflowing the western crater rim in November 2009, no further increase in volume was perceivable. For this reason, rockfalls generated at the lobe between November 2009 and June 2011 are assumed to represent the total extrusion of magma. 


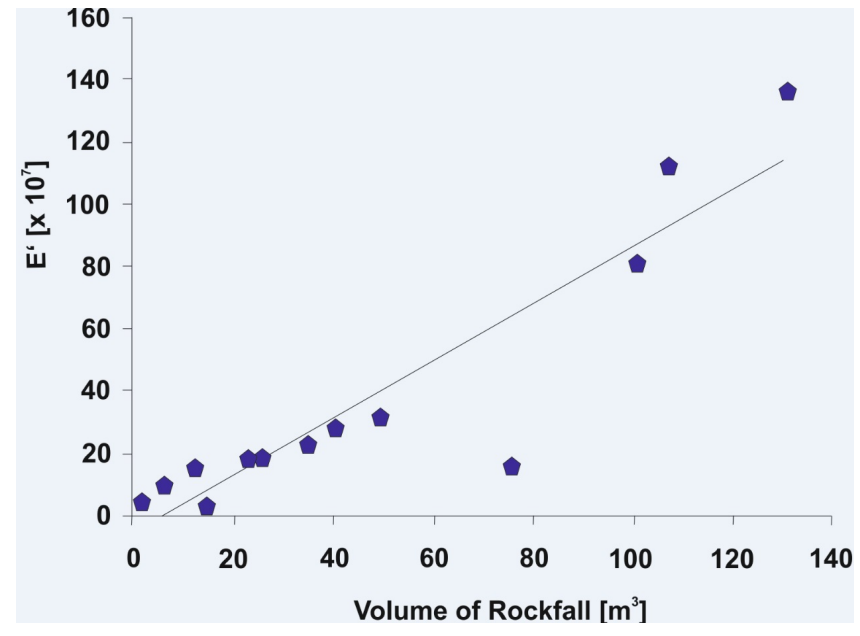

Fig. 9. Rockfall volume vs. seismic signal related energy with averaged trend line. A good correlation was obtained between estimated volume and seismic signal energy value $E^{\prime}$ which is a pseudo - energy and stands for a number that is approximately proportional to the actual seismic energy without units. $R^{2}$ between $E^{\prime}$ and rockfall volume is 0.92 .

Two approaches for constraining the magma extrusion rate were employed using the calibrated seismic data. In the first simplified method, rockfalls for the whole year of 2010 were classified into three classes depending upon the level of the associated seismic signal. In the second method, individual seismic energies, $E^{\prime}$, were estimated for March 2011 events, during which most field data was obtained. After analysing and comparing the results of the two methods, it appears that the estimated proxy for the energy of the signal $E^{\prime}$ is much more accurate. The first method requires much less analysis and would be suitable to obtain quick estimates of effusion rates.

For the first method, the average volumes of rockfalls for the three classes were assigned while counting the number of rockfalls per day. Taking the mean of all 23 estimated volumes resulted in $56.6 \mathrm{~m}^{3}$ per rockfall. The three categories were small, medium and large. A volume was assigned to each type based upon the estimated volumes from the photographs. It needs to be emphasized that all rockfalls were of a small volume when compared to other volcanoes with higher rates of extrusion.

The first step in this approach was to evaluate the seismic records of each day in 2010 to obtain the total number of rockfalls that year (Fig. 10). The duration of the small rockfalls usually was less than one minute and the amplitude was about $33 \%$ of the saturation threshold. The volume of six small events has been estimated. Clearly estimating missing rock volumes from the photographs is far less accurate for small volumes. For those six events the maximum exposed face temperature difference was $20^{\circ} \mathrm{C}$; the average volume of this rockfall type was $8.7 \mathrm{~m}^{3}$.

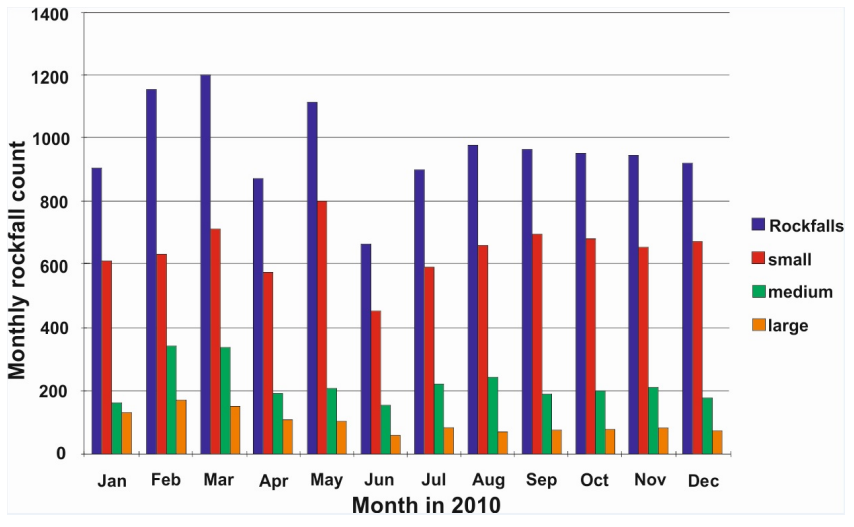

Fig. 10. Total number of rockfalls at Volcán de Colima in 2010. The blue bar shows the monthly total, red shows the small, green the medium and purple the large rockfalls. The small category is defined by the seismic amplitude being smaller than $3 \mathrm{~mm}$ on the helicorder output. They are also usually shorter than $60 \mathrm{~s}$ in duration. The medium category has amplitudes smaller than $7 \mathrm{~mm}$; their duration usually never exceeds $180 \mathrm{~s}$. All rockfalls with an amplitude greater than $7 \mathrm{~mm}$ count as large rockfalls. All the data shown in this figure is gained from the daily helicorder records for the year 2010 of the EZV4/SOMA station in the RESCO Volcán de Colima seismic network.

Medium rockfalls were defined by duration (less than three minutes) and an amplitude between 33 and $66 \%$ of the saturation level. The exposed face temperature difference of these events usually was between 20 and $100^{\circ} \mathrm{C}$, their volume was less than $100 \mathrm{~m}^{3}$. The volume of 12 medium events was estimated and the average was $43 \mathrm{~m}^{3}$.

Large rockfalls lasted for up to at least five minutes and the seismograms ranged between 66 and $80 \%$ of the saturation threshold. Saturation of the signal was only reached with the coincident occurrence of an explosion. $\Delta T$ at the exposed face of these large events was always more than $100^{\circ} \mathrm{C}$; the hottest temperature difference measured for the 23 rockfalls was $200^{\circ} \mathrm{C}$. The volume of 5 large events was estimated, giving an average of $146.7 \mathrm{~m}^{3}$. These events are rare, with a total of only 5 large rockfalls observed.

Taking July 2010 as an example month, there were in total 897 rockfall events recorded. 591 of them were of the small type, 222 medium and 84 of the large rockfall type. So the total volume of magma extruded in July 2010 was estimated at $27000 \mathrm{~m}^{3}$, giving an average magma extrusion rate of $0.010 \mathrm{~m}^{3} \mathrm{~s}^{-1}$. In comparison, taking the mean volume of all 23 calculated events $\left(56.6 \mathrm{~m}^{3}\right)$ instead of classifying them by size, the magma extrusion rate was estimated at $0.019 \mathrm{~m}^{3} \mathrm{~s}^{-1}$ or $90 \%$ greater. This rather high error justifies our approach of grouping rockfalls according to magnitude. For the year 2010, an average magma extrusion rate of $0.011 \mathrm{~m}^{3} \mathrm{~s}^{-1}$ has been established; taking the error of $35 \%$ (see discussion) into account, it ranges between 0.007 and $0.015 \mathrm{~m}^{3} \mathrm{~s}^{-1}$. As shown in Fig. 11, the variation was between 


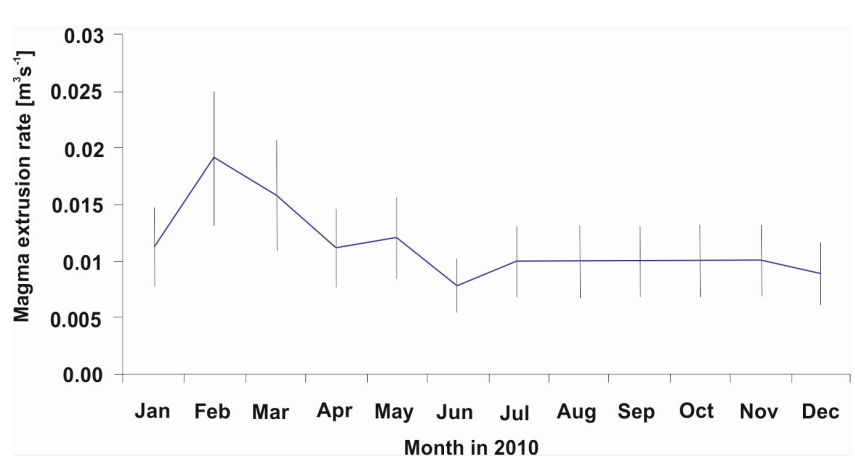

Fig. 11. Magma extrusion rate of Volcán de Colima in 2010, with an error of $35 \%$; calculated with the seismic amplitude - photographic method. The maximum was in February 2010 with $0.019 \mathrm{~m}^{3} \mathrm{~s}^{-1}$, the minimum was in June 2010 with $0.008 \mathrm{~m}^{3} \mathrm{~s}^{-1}$. The average extrusion rate in 2010 was $0.0113 \mathrm{~m}^{3} \mathrm{~s}^{-1}$. In November 2010 the decrease of activity started and finally stopped in June 2011.

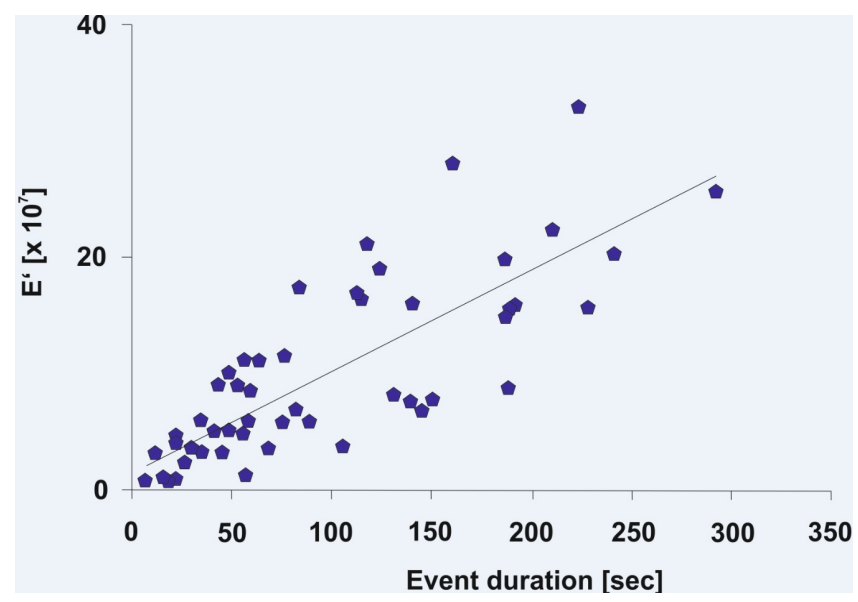

Fig. 12. Pseudo-energy $E^{\prime}$ vs. duration of rockfalls in seconds; $R^{2}$ is 0.8 .

0.008 and $0.019 \mathrm{~m}^{3} \mathrm{~s}^{-1}$ in 2010 with an initial increase in February followed by a general decline.

For the second and more accurate method of extrusion rate calculation, rockfalls occurring during an eruption have been excluded as the superposition of the rockfall and explosion signal prevents a volume interpretation. The integrated velocity squared value $E^{\prime}$ of the seismic signal was calculated, which as discussed, is related to the energy of the rockfall. In an attempt to include a consideration of rockfalls coinciding with explosions, the duration of the rockfalls was considered. For superimposed rockfalls with explosions the frequency spectrogram of the seismic signals was employed. Due to differences in frequency content between explosions and rockfalls, this allowed precise determination of the duration parameter for the majority of superimposed events. Plotting duration against $E^{\prime}$ of pure rockfalls showed only a moderate correlation (Fig. 12).
As a result of applying Eq. (4), we get Eq. (5) which allows the constraint of the volume of eruption related rockfalls using their duration $\mathrm{D}$ :

$V=0.121 D$.

Plotting volume versus duration produces a $R^{2}$ value of 0.8 ; for this analysis, 9 days of observation in March 2011 were used. When rockfalls occurred during an eruption, the duration was used to estimate $E^{\prime}$. There were 701 rockfalls in March 2011, giving an average of 23 per day. During the 9 field days an average of 11 rockfalls a day were observed, a reduced number since observation was not carried out throughout the night.

Applying Eqs. (4) and (5), the total magma extruded in March 2011 was $21000 \pm 7000 \mathrm{~m}^{3}$. The total magma extrusion rate can be divided between $20000 \mathrm{~m}^{3}$ for isolated rockfalls and $1000 \mathrm{~m}^{3}$ of rockfall volume generated during an eruption. The magma extrusion rate at Volcán de Colima during March 2011 was $0.0078 \pm 0.0027 \mathrm{~m}^{3} \mathrm{~s}^{-1}$. This result agrees reasonably with the result shown in Fig. 11, where the magma extrusion rate shows a decrease at the end of 2010 to $0.009 \mathrm{~m}^{3} \mathrm{~s}^{-1}$. Also observations in the field and of the seismicity show that effusive activity gradually decreased after November 2010 until it finally stopped in June 2011.

\section{Discussion}

Rockfalls occur frequently during lava emplacement at active volcanoes; at Volcán de Colima the number and magnitude increased significantly between November 2009 and June 2011 when the summit dome overflowed the western crater rim. In this study, an estimation of rockfall volume through photographic observation was performed. At the outset we note that whereas seismic stations are running constantly with telemetry, the acquisition of thermal images currently requires operator intervention. Of 86 rockfalls recorded visually, 23 were suitable for volume estimates. This can be regarded as representative for several reasons: the full range of rockfall sizes is covered (between 1 and almost $200 \mathrm{~m}^{3}$ ); rockfall numbers correspond to between 20 and $60 \%$ of the entire day count during the 12 field days, carried out during a phase of high rockfall activity. Data was then used for comparison with other measured parameters.

Volume estimation from photographs and subsequent magma extrusion rate calculation includes some inherent error: the dome slope angle due to a large variation of the slope on different parts of the dome, the manually measured rock dimensions in zoomed pictures or the assumption of rocks being perfect cuboids. For our calculations, we assumed an error of $3^{\circ}$ for the slope angle, $1 \mathrm{~mm}$ on the before rockfall pictures $(20 \mathrm{~cm}$ true length) for the length of individual rock axes (in the zoomed photograph) and taking into account that rocks are usually not all parallelepiped. A further source of error is the minimum rock size detectable, which is estimated 
to be $20 \mathrm{~cm}$. However, a rock of these dimensions is still quite small, and even considering a large number of small rocks, the impact on the volume estimation would be negligible.

Calculations using correlations should have minimal error when the correlation coefficient $R^{2}$ is high (such as the case of volume estimate vs. energy when it is 0.92). In case of estimating rockfall volumes from superimposed events (rockfall and eruption) with the seismic records, $R^{2}(0.8$, Fig. 13) is considerably lower. However, only $5 \%$ of the total extruded volume in March 2011 coincided with an explosion, and thus the overall impact should be minimal. Finally, errors arise due to uncertainties on energy estimations: seismic rockfall signals are picked manually, hence there can be minimal errors regarding the picked and true duration of rockfalls which affects the resulting energy value. The high-pass filter removes the majority of background noise (mainly oceanic) but inevitably some noise remains within the seismic signal. After consideration of all possible error sources, a maximum possible relative error of $35 \%$ in the magma extrusion rate has been determined by calculation of the root mean square of combined relative errors. For eruption related rockfalls the volume-duration relation is useful, although less precise than the estimation using $E^{\prime}$. The relationship between rockfall volume and the thermal emission of either the exposed dome face or the material on the flank was less precise, and can easily contain additional error sources.

For estimating rockfall volumes over long periods the continuous seismic data stream is available. With the relations between rockfall volume, duration and pseudo-energy, a final minimum magma extrusion rate of $0.0078 \pm 0.0027 \mathrm{~m}^{3} \mathrm{~s}^{-1}$ for March 2011 and a maximum of $0.019 \pm 0.007 \mathrm{~m}^{3} \mathrm{~s}^{-1}$ for February 2010 have been constrained. This result fits very well with observations of the period $2007-2010$ by Lavallee et al., $2012\left(0.02 \mathrm{~m}^{3} \mathrm{~s}^{-1}\right)$. In March 2011 the rate decreased and finally reached zero in June 2011.

Of course photographic methods for dome monitoring have already been used (e.g. at Soufrière Hills, Sparks et al., 1998 or Ryan et al., 2010), however, in these cases changes in the dome profile was monitored. Sparks et al. (1998) and Ryan et al. (2010) estimated their error in volume calculations to be $15 \%$, but it has to be noted that they concentrated on dome profile lines which are much simpler than using two-dimensional images to estimate volumes in three-dimensions. Since they were observing much larger effusion rates (Ryan et al., 2010 for the 2005-2007 active dome growth period at Soufrière Hills, extrusion rate was $5.6 \pm 0.9 \mathrm{~m}^{3} \mathrm{~s}^{-1}$ ) the absolute error was much larger. In our study, the extraordinary observation conditions permitted an unprecedented opportunity to look in detail at small rockfalls, which represented the only new material being emplaced. With similar conditions, that is the possibility of close-up rockfall observation and a suitably closely located seismic station, the methodology presented here should be adapted for other volcanoes.
The relationship between pseudo-energy and the volume of rockfalls has, in a different way, also been described by Hibert et al. (2011). By studying the connection between seismic and potential energy in granular flow and combining an analytical approach with experimental work on moving granular flows, they defined a methodology for estimating rockfall volumes at Piton de la Fournaise, Réunion. They also suggest their method could be used for real-time rockfall volume monitoring at active volcanoes.

The methodology developed in this study could be used for future periods of effusive activity at Volcán de Colima. The presented seismic correlation is limited to this volcano because $E^{\prime}$ is dependent on volcano-specific parameters, such as dome slope angle, density of rock material, run-out distance and slope angle and the distance between the seismic station and dome. Nevertheless, the technique could be applicable for other volcanoes exhibiting similar phenomena provided a site specific calibration is obtained in each case. A further complication would be inherent if rockfalls were to occur in more than one direction. The applicability for the presented method requires a decentralized slow growing dome in the summit crater which produces small rockfalls on the western flank of the volcano. If the dome has a different relative position within the summit crater, the recorded seismicity would have different characteristics because of new parameters (slope gradient, distance to EZV4 seismic station). Furthermore, different magma properties (volatile contents, temperature, chemical composition, crystal contents) or a different effusion rate would lead to different dome growth characteristics and hence a variation in the generation of rockfalls. If direct observation is possible, further rockfall volume estimation could be performed to freshly calibrate the associated seismic signal. Volume estimation of rockfalls is definitely possible after individual calibration for other volcanoes; an estimation of magma effusion rate would only be possible, though, if no significant volume increase of the active growing dome takes place; all freshly emplaced lava must end up being lost in rockfalls. During late 20092011 at Volcán de Colima, almost all rockfalls descended the western flank following an almost identical path. Rockfalls descending a volcano on different flanks would introduce further complications for interpretation of the seismicity. While we appreciate these obvious flaws, we contend that our practical and simple method provides a reliable approximation for the magma extrusion rate at volcanoes that continuously shed their lava dome through rockfall activities.

\section{Conclusions}

We propose a methodology for the detailed monitoring of rockfall volume to estimate the magma extrusion rate of volcanoes with active domes. The example of Volcán de Colima illustrates that if dome growth is dominated by rockfalls, the method succeeds in yielding a reasonably accurate 
estimation of the extrusion rate. The rockfall volume was obtained from comparing photographic images before and after the events. The relationship with two other parameters (thermal and seismic data) was shown and proven suitable to estimate rockfall volume once calibrated by using a number of direct estimates from photographic images. The thermal emission recorded was either the mean temperature at the freshly exposed face on the dome directly after the rockfall or the mean rockfall temperature on the slope of the volcano. The correlation between mean rockfall temperature and volume has been shown to be the more accurate of the two. The second and more important relationship used to estimate rockfall volumes was the comparison with the seismic signals. The relationship between $E^{\prime}$ and the rockfall volume $V$ showed an astonishingly good correlation coefficient (0.92). Seismic monitoring can thus be used as a powerful tool for extrusion rate monitoring of certain active volcanoes. We recommend that these methods be considered for risk assessment in dome-building eruptive centres.

Acknowledgements. We thank all the CIIV interns who helped in the data collection needed for this study, particularly Magret Damaschke. Varley was supported by UdeC FRABA projects $668 / 10$ and 768/11.

Dingwell was supported by a research professorship of the Bundesexzellenzinitiative (LMUexcellent) and the EVOKES advanced researcher grant of the European Research Council (247076).

Edited by: M. Heap

\section{References}

Arámbula-Mendoza, R., Lesage, P., Valdéz-Gonzales, C., Varley, N. R., Reyes-Dávila, G., and Navarro, C.: Seismic activity that accompagnied the effusive and explosive eruptions during the 2004-2005 period at Volcán de Colima, Mexico, J. Volcanol. Geoth. Res., 205, 30-46, 2011.

Barmin, A., Melnik, O., and Sparks, R. S. J.: Periodic behavior in lava dome eruptions, Earth. Planet Sci. Lett., 199, 173-184, 2002.

Blake, S.: Viscoplastic models of lava domes, 1990, in: Lava flows and domes, edited by: Fink, J. H. and Wagner, G., Berlin, Springer, 88-126, 1990.

Calder, E. S., Cortés, J. A., Palma, J. L., and Luckett, R.: Probalistic analysis of rockfall frequencies during an andesite lava dome eruption: The Soufrière Hills Volcano, Montserrat, Geophys. Res. Lett., 32, L16309, doi:10.1029/2005GL023594, 2005.

Calvari, S., Lodato, L., Steffke, A., Cristaldi, A., Harris, A. J. L., Spampinato, L., and Boschi, E.: The 2007 Stromboli eruption: event chronology and effusion rates using thermal infrared data, J. Geophys. Res., 115, B04201, doi:10.1029/2009JB006478, 2010 .
Dammeier, F., Moore, J. R., Haslinger, F., and Loew, S.: Characterization of alpine rockslides using statistical analysis of seismic signals, J. Geophys. Res., 116, F04024, doi:10.1029/2011JF002037, 2011.

DeRoin, N., McNutt, S. R., Sentman, D. D., and Reyes, C.: Seismicity of block and ash flows occurring during the 2006 eruption of Augustine Volcano, Alaska, J. Volcanol. Geoth. Res., 213-214, 14-26, 2012.

DeRoin, N. and McNutt, S. R.: Rockfalls at Augustine Volcano, Alaska: The influence of eruption precursors and seasonal factors on occurrence patterns 1997-2009, J. Volcanol. Geoth. Res., 211-212, 61-75, 2012.

Fink, J. H., Malin, M., and Anderson, S. W.: Intrusive and extrusive growth of the Mount St. Helens lava dome, Nature, 348, 435437, 1990.

Gil Cruz, F. and Chouet, B. A.: Long-period events, the most characteristic seismicity accompanying the emplacement and extrusion of a lava dome in Galeras Volcano, Colombia, in: 1991, J. Volcanol. Geoth. Res., 77, 121-158, 1997.

Hibert, C., Mangeney, A., Grandjean, G., and Shapiro, N. M.: Slope instabilities in Dolomieu crater, Réunion Island: From seismic signals to rockfall characteristics, J. Geophys. Res., 116, F04032, doi:10.1029/2011JF002038, 2011.

Hort, M., Vöge, M., Seyfried, R., and Ratdomopurbo, A.: In situ observation of dome instabilities at Merapi Volcano, Indonesia: a new tool for hazard mitigation, J. Volcanol. Geoth. Res., 153, 301-312, 2006.

Jongmans, D. and Garambois, D.: Geophysical investigation of landslides: A review, Bulletin Société de France, 178, 101-112, 2007.

Kaneko, T., Wooster, M. J., and Nakada, S.: Exogenous and endogenous growth of the Unzen lava dome examined by satellite infrared image analysis, J. Volcanol. Geoth. Res., 116, 151-160, 2002.

Kennedy, B. M., Jellinek, M., Lavallee, Y., Von Aulock, F., Russell, K., Wadsworth, F.: The formation of volcanic plugs and domes by collapsing foam, COV Abstract, 2012.

Kolzenburg, S., Heap, M. J., Lavallée, Y., Russell, J. K., Meredith, P. G., and Dingwell, D. B.: Strength and permeability recovery of tuffisite-bearing andesite, Solid Earth, 3, 191-198, doi:10.5194/se-3-191-2012, 2012.

Lavallée, Y., Varley, N., Alatorre-Ibargüengoitia, M. A., Hess, K. U., Kueppers, U., Mueller, S., Richard, D., Scheu, B., Spieler, O., and Dingwell, D. B.: Magmatic architecture of dome-building eruptions at Volcán de Colima, Mexico, B. Volcanol, 74, 249260, 2012.

Lesage, P.: Interactive Matlab software for the analysis of seismic volcanic signals, Comput. Geosci., 35, 2137-2144, 2009.

Loughlin, S. C., Luckett, R., Ryan, G., Christopher, T., Hards, V., De Angelis, S., Jones, L., and Strutt, M.: An overview of lava dome evolution, dome collapse and cyclicity at Soufriere Hills Volcano, Montserrat, 2005-2007, Geophys. Res. Lett., 37, L00E16, doi:10.1029/2010GL042547, 2010.

Luhr, J. and Carmichael, I.: The Colima Volcanic Complex, Mexico, Contrib. Mineral. Petr., 71, 343-372, 1980.

Major, J. J., Dzurisin, D., Schilling, S. P., and Poland, M. P.: Monitoring lava-dome growth during the 2004-2008 Mount St. Helens, Washington, eruption using oblique terrestrial photography, Earth Planet. Sci. Lett., 286, 243-254, 2009. 
Menyailov, I. A., Nikitina, L. P., Shapar, V. N., and Pilipenko, V. P.: Temperature increase and chemical change of fumarolic gases at Momotombo Volcano, Nicaragua, in: 1982-1985: Are these indicators of a possible eruption?, J. Geophys. Res., 91, B12, 199_ 214, doi:10.1029/JB091iB12p12199, 1986.

Moran, S. C., Matoza, R. S., Garcés, M. A., Hedlin, M. A. H., Bowers, D., Scott, W. E., Sherrod, D. R., and Vallance, J. W.: Seismic and acoustic recordings of an unusually large rockfall at Mount St. Helens, Washington, Geophys. Res. Lett., 35, L19302, doi:10.1029/2008GL035176, 2008.

Nakada, S.: Characteristics of lava dome eruption and dome growth model at Unzen Volcano (in Japanese with English abstract), Mem. Geol. Soc. Jpn., 46, 139-148, 1996.

Nakada, S., Myake, Y., Sato, H., Oshima, O., and Fujinawa, A.: Endogenous growth of dacite dome at Unzen Volcano (Japan), Geology, 23, 157-160, 1995.

Norris, R. D.: Seismicity of rockfalls and avalanches at three Cascade Range volcanoes: Implications for seismic detection of hazardous mass movements, Bull. Seismol. Soc. Am., 84, 19251939, 1994.

Rose, W. I.: Pattern and mechanism of volcanic activity at the Santiaguito volcanic dome, Guatemala, B. Volcanol., 36, 73-94, 1972.

Rose, W. I., Pearson, T., and Bonis, S.: Nueé ardent eruption from the foot of a dacite lava flow, Santiaguite Volcano Guatemala, B. Volcanol., 40, 53-70, 1977.

Ryan, G. A., Loughlin, S. C., James, M. R., Jones, L. D., Calder, E. S., Christopher, T., Strutt, M. H., and Wadge, G.: Growth of the lava dome and extrusion rates at Soufriere Hills Volcano, Montserrat, West Indies: 2005-2008, Geophys. Res. Lett., 37, L00E08, doi:10.1029/2009GL041477, 2010.

Shearer, P. M.: Introduction to Seismology, Cambridge University Press, 2 edition, 408 p., 2009.

Smith, R., Sammonds, P. R., Tuffen, H., and Meredith, P. G.: Evolution of the mechanics of the 2004-2008 Mt. St. Helens lava dome with time and temperature, Earth Planet. Sci. Lett., 307, 191-200, 2011.

Spaminato, L., Calvari, S., Oppenheimer, C., and Boschi, E.: Volcano surveillance using infrared cameras, Earth. Sci. Rev., 106, 63-91, 2011.

Sparks, R. S. J., Young, S. R. , Barclay, J., Calder, E. S., Cole, P., Darroux, B., Davies, M. A., Druitt, T. H., Harford, C., Herd, R., James, M., Lejeune, A. M., Loughlin, S., Norton, G., Skerrit, G., Stasiuk, M. V., Stevens, N. S., Toothill, J., Wadge, G., and Watts, R.: Magma production and growth of the lava dome of the Soufrière Hills Volcano, Montserrat, West Indies: November 1995 to December 1997, Geophys. Res. Lett., 25, 3421-3424, 1998.
Stevenson, J. A. and Varley, N. R.: Fumarole monitoring with a handheld infrared camera: Volcán de Colima, Mexico, 20062007, J. Volcanol. Geoth. Res., 177, 911-924, 2008.

Sulpizio, R., Capra, L., Sarocchi, D., Saucedo, R., Gavilanes-Ruiz, J. C., and Varley, N. R.: Predicting the block-and-ash flow inundation areas at Volcán de Colima (Colima, Mexico) based on the present day (February 2010) status, J. Volcanol. Geoth. Res., 193, 49-66, 2010.

Taron, J., Elsworth, D., Thompson, G., and Voight, B.: Mechanisms for rainfall concurrent lava dome collapses at Soufrière Hills Volcano, 2000-2002, J. Volcanol. Geoth. Res., 160, 195-209, 2007.

Varley, N. R., Arámbula-Mendoza, R., Reyes-Dávila, G., Stevenson, J., and Harwood, R.: Generation of Vulcanian activity and long-period seismicity at Volcán de Colima, Mexico, J. Volcanol. Geoth. Res., 198, 45-46, 2010a.

Varley, N. R., Arámbula, R., Reyes, G., Stevenson, J., and Harwood, R.: Long-period seismicity during magma movement at Volcán de Colima, B. Volcanol., 72, 1093-1107, 2010b.

Varley, N. R. and Reyes, G. A.: Monitoring the Recent Activity: Trying to Understand the Eruptive Mechanism, in: Volcán de Colima: managing the threat, edited by: Varley, N. R. and Komorowski, J. C., Springer, in preparation, 2013.

Vilajosana, I., Suriñach, E., Abell an, A., Khazaradze, G., Garcia, D., and Llosa, J.: Rockfall induced seismic signals: case study in Montserrat, Catalonia, Nat. Hazards Earth Syst. Sci., 8, 805-812, doi:10.5194/nhess-8-805-2008, 2008.

Zobin, V. M., Luhr, J. F., Taran, Y. A., Bretón, M., Cortés, A., De La Cruz-Reyna, S., Domínguez, T., Galindo, I., Gavilanes, J. C., Muñìz, J. J., Navarro, C., Ramìrez, J. J., Reyes, G. A., Ursúa, M., Velasco, J., Alatorre, E., and Santiago, H.: Overview of the 1997-2000 activity of Volcán de Colima, Mexico, J. Volcanol. Geoth. Res., 117, 1-19, 2002.

Zobin, V. M., Varley, N. R., Gonzalez, M., Orzco, J., Reyes, G. A., Navarro, C., and Breton, M.: Monitoring the 2004 andesitic block-lava extrusion at Volcan de Colima, Mexico from seismic activity and $\mathrm{SO}_{2}$ emission, J. Volcanol. Geoth. Res., 177, 367377, 2008. 